\title{
Developing and Implementing Mother-tongue Education Policy in Minority Speech Communities in Nepal: Issues and Challenges ${ }^{1}$
}

\author{
Dan Raj Regmi \\ Tribhuvan University, Nepal \\ danrajregmi8@gmail.com
}

\section{Abstract}

This paper examines some major issues and challenges in developing and implementing mother-tongue education policy in minority speech communities in Nepal. It also suggests some strategies based on field studies for meeting those challenges. In minority speech communities, constituting more than 55\% of total population and speaking around 70 languages, despite attempts made by governmental and non-governmental agencies, multilingual education has not yet become accessible it is mainly due to the lack of operational mechanism in education policy. Till today, thousands of children of non-Nepali speaking communities are compelled to be instructed in Nepali and use the textbooks written in Nepali. This has resulted in class repetition, high dropout and very low quality at primary levels.

The case studies made in Western Tamang and Rajbansi have explored a number of challenges as well as some way-outs for effective implementation of mother-tongue education policy in such communities. First and foremost, the roles of mother tongue, Nepali and English have not yet been fully justified. In most of the minority speech communities, there is only sentimental attitude towards their mother tongue. Most of the MLE programmes have been commenced without conducting need assessment (Regmi, 2019). There is a lack of appropriate textbooks and reading materials incorporating local cultures and life crucial knowledge embodied in language. Due to the lack of trained and motivated teachers, programmes so far implemented are also facing the problem of quality maintenance. Thus, a promising and inclusive multilingual education policy should be developed and implemented for maintaining the sustainability of MLE programmes in minority speech communities in Nepal.

Keywords: mother-tongue education, minority speech communities, monolingual ideology, sustainable language use, medium of instruction

\section{Background}

1 This paper was presented at $6^{\text {th }}$ International Conference on the Inclusion, Mobility and Multilingual Education : Exploring the Roles of Languages for Education and Development organized in partnership by Asia Pacific Multilingual Education Working Group, British Council and Language and Development Conference Series held at Amari Watergate Bangkok, Thailand on 24-26 September 2019. 
This paper attempts to examine/identify some major issues and challenges in developing and implementing mother-tongue education policy in the minority speech communities in Nepal and suggests some strategies with reference to mother-tongue education implemented in Western Tamang and Rajbansi for meeting those challenges. Nepal, in the midst of 123 mother tongues belonging to five language families (including one language isolate) spoken by 125 castes/ ethnicities (CBS, 2012), has legally acknowledged quality basic education in mother tongue as a fundamental right. In this regard, there have been made some attempts on behalf of governmental bodies. However, they have been mostly criticized as lacking operational mechanism and commitment (Yadava, 2010). Till the date, a promising mother-tongue education policy with an effectual framework for inclusive and equitable quality basic education has not yet been developed in Nepal. Indeed, mother-tongue education policy is a socio-cultural and political process. Such a process, in Nepal, has been procrastinated thanks to inactiveness shown by the concerned bodies to identify theoretical and methodological issues in developing and challenges in implementing such policy in the minority speech communities in Nepal. Historically, indigenous language communities were deliberately minoritized by the language policy based on monolingual ideology taken up prior to the reinstate of democracy in 1990. Due to such policy, more than $56 \%$ languages, mostly spoken by minority/indigenous communities have been forced to be broadly labeled as "threatened and shifting" (Regmi, 2018a). Till today, thousands of children of minority language communities are compelled to be instructed in Nepali (viz., the language of dominant group in terms of number and power) and use the textbooks written in Nepali. This is contributing to class repetition, high dropout and very low quality in education in the primary levels. ${ }^{2} \mathrm{~A}$ few studies have been made on the policy and practices of mother tongue education in Nepal. They include SkutnabbKangas \& Mohanty (2009), Kainla et al.(2009), Regmi (2012), Yonjan-Tamang (2069 BS), Yadava (2013; 2018), Regmi and Regmi (2016a; 2019), Seel et al. (2017), Yadava et al. (2017) and Tamang ( 2019). However, no attempt has exclusively been made to identify issues and challenges in developing and implementing mother tongue education policy in the minority speech communities in Nepal.

This paper has been organized into nine sections. Section 2 looks at the sociolinguistic situation of minority languages in Nepal. In section 3, I have briefly reviewed the attempts made for developing mother tongue education policy in Nepal. Section 4 briefly makes a review of MT education implemented in Rajbansi and Western Tamang. In section 5, I propose an outline of MT education

2 There may be other factors for contributing the dropout rates such as the socio-economic background of parents, the literacy rate of parents among others. However, dealing with such factors is beyond the scope of the paper. 
policy in minority speech communities in Nepal. Section 6 identifies issues in developing MT education policy in minority speech communities in Nepal. In section 7, I enumerate the challenges in implementing MT education policy in those communities in Nepal. Section 8 suggests some strategies for meeting those challenges in developing and implementing MT education policy in Nepal with reference to the mother tongue education implemented in Western Tamang and Rajbansi. In section 9, I summarize the paper with a conclusion.

\section{Socio-linguistic Situation of Minority Languages}

Till today, Nepal has been unable to provide a reliable statistics on the languages/ dialects and their speakers due to the lack of conducting a free and scientific census of languages/dialects. Data gleaned by 2011 national census based on very limited and impractical questionnaire are erroneous and almost useless for any policy framing regarding the use of mother tongues in education (Regmi, 2018b). Seel et al. (2015) have categorized the minority languages solely in terms of number of speakers. ${ }^{3}$ The real number of speakers in such minority languages is expected to be much lower than those enumerated in the 2011 census. ${ }^{4}$ Skutnabb-Kangas \& McCarty (2007) suggest two criteria for categorizing languages: power and number of speakers. ${ }^{5}$ Power is the most reliable criteria. Thus, Regmi (2018a) has categorized minority languages as lacking official status and being spoken as indigenous languages by a numerically smaller number of speakers (viz., by less than 0.1 million speakers). In Nepal, except Nepali, Maithili, Bhojpuri, Tharu, Tamang, Newar, Magar, Avadhi, Bantawa, Gurung, Limbu, Bajjika, Urdu, Rajbansi, Sherpa, Achhami, Baitadeli and Doteli, the rest of the languages are spoken by less than 0.1 million speakers (Regmi,2018a). Sociolinguistic survey of most of the minority languages have been completed (Regmi, 2017). Such languages have different patterns of use (Yadava, 2014).

In Nepal, ceremonially, all the languages spoken as mother-tongues are referred to as languages of nation. However, Nepali (spoken by $44.1 \%$ as mother tongue) enjoys almost exclusive role of official language as well as medium of instruction

3 In Seel et al. (2015) 19 languages with over 100,000 speakers are categorized as major and 104 as minor languages accounting for $96 \%$ and $4 \%$ speakers, respectively. There are 30 minor languages $(10,000$ to 99,999 speakers), 37 minor languages (1000 to 9,999 speakers) and 37 minor languages (with less than 1000 speakers).

4 In 2011 census, the number of speakers also includes the number of those community members who long for being identified with their ancestral language.

5 In terms of the number of speakers, Rabansi, an Indo-Aryan language mainly spoken in Jhapa and Morang districts of Nepal is a major language. Western Tamang, a major dialect of Tamang (a major language) may not be rightly called a minority language. However, in terms of power, both are not dominant languages at all. They are minority languages. 
in the basic education. In reality, almost minority languages are facing different levels of language endangerment. They are used for limited and traditional domains of language use. Such languages, in general, are lagging behind in being effectively used in education. Such situation is briefly discussed here:

Vitality of minority languages. In Nepal, there are some minority languages in terms of speakers spoken as non-indigenous languages. Excluding nonnative languages, Nepal tentatively accommodates 70 minority languages. They are spoken by only $17.3 \%$ of the total population (CBS, 2012). Moreover, such speech communities are gradually shifting to Nepali and other dominant languages. In 2001 Census, such languages were recorded to have been spoken by $18.8 \%$ of the total population (Regmi, 2018c). Out of languages enumerated by 2011 census, only around 53 (43.1\%) languages are safe or vigorous (Regmi, 2017a). Table 1 presents the situation of the vitality of the minority languages of Nepal assessed within the framework of the Expanded Graded Intergenerational Disruption Scale model proposed by Lewis and Simons (2010).

Table 1: Situation of the Vitality of the Minority Languages of Nepal

\begin{tabular}{|c|c|c|c|c|}
\hline & $\begin{array}{l}\text { Vitality } \\
\text { labels }\end{array}$ & Description & $\begin{array}{l}\text { No. of } \\
\text { languages }\end{array}$ & $\%$ \\
\hline 1. & Threatened & $\begin{array}{l}\text { The language is used orally by all } \\
\text { generations but only some of the child } \\
\text { bearing generations are transmitting it to } \\
\text { their children. }\end{array}$ & 51 & $72.9 \%$ \\
\hline 2. & Shifting & $\begin{array}{l}\text { The child-bearing generation knows the } \\
\text { language well enough to use it among } \\
\text { themselves but none are transmitting it to } \\
\text { their children. }\end{array}$ & 11 & $15.7 \%$ \\
\hline 3. & Moribund & $\begin{array}{l}\text { The only remaining active speakers of the } \\
\text { language are members of the grandparent } \\
\text { generation. }\end{array}$ & 6 & $8.6 \%$ \\
\hline 4. & $\begin{array}{l}\text { Nearly } \\
\text { extinct }\end{array}$ & $\begin{array}{l}\text { The only remaining speakers of the language } \\
\text { are members of the grandparent generation } \\
\text { or older who have little opportunity to use } \\
\text { the language. }\end{array}$ & 1 & $1.4 \%$ \\
\hline \multirow[t]{2}{*}{5.} & Extinct & $\begin{array}{l}\text { The language serves as a reminder of } \\
\text { heritage identity for an ethnic community. } \\
\text { No one has more than symbolic proficiency. }\end{array}$ & 1 & $1.4 \%$ \\
\hline & & & 70 & $100 \%$ \\
\hline
\end{tabular}


Table 1 illustrates that only $72.9 \%$ of the minority languages are used orally by all generations. In such languages, MT education may be implemented by framing a promising policy with proper coordination with the concerned stakeholders. Likewise, $15.7 \%$ (11) languages are shifting. These languages are not being transmitted to the younger generations at all. Around $8.6 \%(6)$ are moribund. Similarly, $1.4 \%(1)$ is nearly extinct and $1.4 \%(1)$ is extinct. This situation is indeed appealing in Nepal.

Sustainable language use. No comprehensive study has yet been made on the sustainable language use in Nepal. Regmi (2019) has broadly categorized a total of 91 languages (excluding some non-indigenous languages) enumerated in 2011 census which have been broadly categorized into four sustainable usebased levels: sustainable literacy, sustainable orality, sustainable identity and sustainable history. Sustainable orality in the present context of multilingualism has to be further sub-categorized as sustainable orality (a) for vigorous languages and sustainable orality (b) for threatened language. Table 2 presents the levels of sustainable use of the languages of Nepal. 
Table 2: Levels of Sustainable Language Use in Nepal

\begin{tabular}{|c|c|c|c|c|}
\hline & $\begin{array}{l}\text { Levels of } \\
\text { Sustainable Use }\end{array}$ & Description & $\begin{array}{l}\text { No. of } \\
\text { Languages }\end{array}$ & $\%$ \\
\hline 1. & $\begin{array}{l}\text { Sustainable } \\
\text { literacy }\end{array}$ & $\begin{array}{l}\text { Not only vigorous oral use but } \\
\text { widespread written use, supported } \\
\text { (transmitted) by sustainable } \\
\text { institutions for education }\end{array}$ & 8 & $8.8 \%$ \\
\hline 2. & $\begin{array}{l}\text { Sustainable } \\
\text { orality (a) }\end{array}$ & $\begin{array}{l}\text { Strong identity rooted in the } \\
\text { language, vigorous oral use by } \\
\text { all generations for day-to-day } \\
\text { communication and language } \\
\text { transmission takes place in the } \\
\text { family or local community }\end{array}$ & 30 & $33 \%$ \\
\hline 3. & $\begin{array}{l}\text { Sustainable } \\
\text { orality (b) }\end{array}$ & $\begin{array}{l}\text { Less strong identity rooted in the } \\
\text { language, less vigorous oral use } \\
\text { by all generations for day-to-day } \\
\text { communication and language } \\
\text { transmission takes place in the } \\
\text { family or local communities in some } \\
\text { particular areas }\end{array}$ & 51 & $56 \%$ \\
\hline 4. & $\begin{array}{l}\text { Sustainable } \\
\text { identity }\end{array}$ & $\begin{array}{l}\text { No fully proficient speakers, a } \\
\text { community associates its identity } \\
\text { with the language, not used for } \\
\text { day-to-day communication; used } \\
\text { ceremonially or symbolically }\end{array}$ & 1 & $1.1 \%$ \\
\hline \multirow[t]{2}{*}{5.} & $\begin{array}{l}\text { Sustainable } \\
\text { history }\end{array}$ & $\begin{array}{l}\text { No remaining speakers, no one } \\
\text { associates their identity with } \\
\text { the language and a permanent } \\
\text { record (history) of the language is } \\
\text { preserved }\end{array}$ & 1 & $1.1 \%$ \\
\hline & & & 91 & $100 \%$ \\
\hline
\end{tabular}

Source: Revised in Regmi (2019)

Table 2 shows that one-third languages fall into the category of the sustainable orality (a) and $56 \%$ languages are categorized as sustainable orality (b) in Nepal. ${ }^{6}$ Such categories in Nepal have not been fully satisfactorily discussed. The lan-

6 See Annex 1 for detail 
guages with sustainable orality have been categorized as 6a (vigorous) and the languages with somewhat orality have been defined as $6 \mathrm{~b}$ (threatened) (Eppele et al., 2012). It is to be noted that both are used orally by all generations; however, threatened ones are transmitted to the younger generations only by some child bearing generations. In Nepal, 30 languages (i.e., 33\%) may be labeled as $6 a$ (vigorous) and 51 languages (i.e., 56\%) may be labeled as threatened. Of sustainable orality category (a) around $46.7 \%$ languages belong to the Tibeto-Burman language family. They are spoken by marginalized communities located in different geographical regions. In Nepal, six languages, viz., Tamang, Tharu, Rajasthani (Marwari), Rajbansi, Lhomi and Sherpa are effectively used in written form in parts of the community (Regmi, 2018c, p. 43). Only in eight languages (i.e., $8.8 \%$ ), literacy is being transmitted through a system of public education. The language which serves as a reminder of heritage identity for Hindu Brahmin communities is exclusively Sanskrit. It may be labeled as sustainable identity. Till the date, Waling, a Tibeto-Burman language, no ethnic community is associating its identity with that language, even for symbolic purpose. It is to be noted that in minority speech communities with sustainable orality category (b) demands a slightly different operational strategies in the MT education policy.

Use of minority languages in education. Nepal lacks a reliable statistics on the use of minority languages in education. Undoubtedly, in Nepal, the issues related to minority/ethnic languages were deliberately ignored in favor of Nepali (spoken by around $44.1 \%$ ) as official and language of instruction in schools. Thus, the rest of the languages were functionally marginalized (Regmi and Regmi, 2016). Most of the indigenous languages are preliterate except Newar, Limbu, Magar, Tamang, Sherpa, Lepcha and Gurung. Neither has such languages been fully or satisfactorily described nor they have been fully used. Still, children in most ethno-linguistic communities are deprived of basic education in their respective mother tongues. Teaching materials prepared so far by governmental and non-governmental agencies have not yet been fully utilized. Unofficially, many minority languages have been partially used in teaching children from non-dominant language communities in Nepal. However, officially, only a few minority languages/dialects have been fortunate to be used in education in $\mathrm{Ne}-$ pal. They include: Western Tamang, Athpahariya, Dhut Magar, Santhali, Orao, Rana Tharu (under Multilingual Education Program, 2015). Apart from these languages, Newar, Limbu, Rajbansi, Lhomi, Lhowa, Tamang (Eastern), Urdu have also been used in basic education. In 26 languages, MT teaching materials have been produced by CCD, Gov/N. 


\section{MT Education Policy in Nepal}

MT education policy is urgently required to improve access to and quality of education of minority children and promote diversity in multilingual country like Nepal. However, no attempt has yet been made to frame a separate MT education policy especially for the minority speech communities in Nepal. On 14 September 1990, Nepal ratified the Convention on the Rights of the Child (1989). This, indeed, obliged Nepal to include some provisions for providing opportunities to the minority speech communities to learn and receive education for their children in the minority languages. Such provisions, though sketchy, have been sparsely included in the constitution, official acts and some documents came into view in Nepal. The Constitution of Kingdom of Nepal, 1990 conferred the right to each community to run schools for the children in its mother tongue up to the primary level (Part 3, Article 18). NLPRC (1994) recommended the government to provide education through the mother tongue in schools with mother-tongue speaking children in Nepal. Local Self-governance Act (1998) authorized local to run primary schools in mother tongues. Nepal, being committed to the World Education Forum in Dakar 2000, announced that all children, particularly girls and children from ethnic minorities would have access to complete free and compulsory primary education of good quality by 2015 . They would have right to receive education of good quality at inclusive schools as per the EFA Core Document. Accordingly, in 2002, Education Act and Education Regulations were amended making provisions for running primary schools in mother tongues. The Interim Constitution of Nepal, 2007 reaffirmed the right to each community to get basic education in their mother tongue as provided for in the law (Part 3, Article 17). The Curriculum of Primary Education, 2007 has also authorized the concerned stakeholders to impart primary education in respective mother tongues. Likewise, National Curriculum Framework, 2007 has stated that the first phase of basic education (1-3) can be imparted in mother tongue. The Three Year Interim Plan, 2007 had also focused on the institutionalization of education in mother tongue and expansion of such program in par with the demand and promotion of multilingual education. Implementation Guidelines, 2005 for District Curriculum Coordination Committee and Regional Curriculum Coordination Committee have also made provisions for developing curriculum and teaching materials at the local level. Multilingual Education Implementation Guidelines, 2010 reaffirmed child right to receive quality basic education in mother tongue. Based on "bottom-up" approach, it has acknowledged the prominent role of the language communities, school management committees, local bodies, nongovernmental organizations in establishing child right to receive quality basic education in mother tongue. It has prescribed local mother tongue as medium of 
instruction for all subjects at pre-primary whereas such medium is prescribed for all subjects except Nepali and English in classes 1-3. However, bilingual education (mother tongue and language of official use) has been recommended for for all subjects except Nepali and English in classes 4-5 whereas bilingual (mother tongue and language of official use) or other tongue may be used in classes 6-8. The Constitution of Nepal, 2015 framed on the principles of federalism and socialism, has again reasserted the right to every citizen to get quality education in its mother tongue in accordance with law. Local Government Operation Act, 2017 has authorized local bodies to provide approval, monitor and regulate schools providing education in mother tongue. A framework for Mother TongueBased Multilingual Education (MTB MLE) in Nepal in the context of federalism has been framed (Yadava, 2017). Compulsory and Free Education Act, 2018 has further broadened the provisions of MT education in Nepal. This act reaffirms the right to every Nepali community residing in Nepal to acquire education up to the basic level or secondary level in his or her own mother tongue as per the law. Such community may set up and operate separate school or teaching institute to provide education in mother tongue. Moreover, government may make arrangement to set up and operate schools or teaching institutes to provide mother tongue education. This act has further provisioned for mother tongue education on any particular subject for Nepali citizens as per the demands in the educational institutes or public schools operated or granted by the Government of Nepal, Provincial Government or Local Level. Nepali, English or both or mother tongue of the Nepali community concerned have been prescribed as medium of instruction at schools. Language Commission has been authorized to conduct feasibility study on use of mother tongue in education. New education policy has not yet come into view. It is to be noted that no clear operational mechanism is reflected in the provisions made for the use of mother tongue in the minority speech community. Minority speech communities, which are marginalized socioeconomically and politically, may not be in position to set up schools to provide education in mother tongue in Nepal.

\section{MT Education in Rajbansi and Western Tamang}

MT education was implemented in Rajbansi with a view of assuring quality basic education, reducing drop-out rate, encouraging regular attendance, assisting cognitive development in the children, transferring the values of traditions, cultures and life-crucial knowledge to the children and boosting up the speech communities to broaden use of mother tongue. While implementing MT education, a number of issues were raised and a number of challenges were faced. With some lessons learnt in Rajbansi, MT education is being implemented 
in Western Tamang. The issues and challenges in the implementation of MT education and strategies made to address those issues and challenges may provide insights for framing and implementing MT education policy in the minority speech communities in Nepal. Thus, they are briefly reviewed as follows:

MT Education in Rajbansi. MT education in Rajbansi was implemented as a project by Nepali National Languages Preservation Institute (NNLPI), a nonprofit making non-governmental organization instituted in 1999 in Dhobighat, Lalitpur and in Jhapa for four and half years (July 2012- November 2016) with the financial and logistic support of SIL, Nepal. Prior to the implementation, a needs assessment was conducted in the Rajbansi speech communities. The goal, approach, issues and challenges as well as strategies used in MT education in Rajbansi are discussed as follows:

Goal and approach of MT education. The main goal was to provide high quality basic education in mother-tongue to non-Nepali speaking children from pre-primary to class five by setting up three new schools in the Rajbansi speech communities in Jhapa. It expected to get 700 students enrolled in three schools during the period. In order to realize the goal, it employed transitional multilingual model based on the framework of MTB-MLE.

Major issues and challenges. There were a number of issues and challenges in framing MT education program. They included: selection of schools and speech communities, framing curriculum and teaching materials, preparing teachers, sequencing of languages as medium of instruction and getting approval (Regmi et al. 2016).

Strategies. The issues and challenges were addressed by framing a number of strategies. They are enumerated as follows:

Coordination. With the coordination of speech communities, local bodies and government agencies, a needs assessment was conducted in the Rajbansi speech community. Selection of the communities was made on the basis of the intensity of the needs and desire identified by the needs assessment. With active participation with local communities, the land was acquired as donation from the community members and three schools buildings [single-storied, seven rooms, toilets] in Amgachi (Korobari-2), Chilhara (Khajurgachi-4) and Harira (Khajurgachi-3) were constructed (NNLPI, 2073 BS). With the approval of local bodies, classes were begun with a new instructional approach. 
Conducting workshops. Workshops were conducted on teaching approach and writing materials. The entire MLE staff was engaged in phonemic approach in teaching language. Participants from the speech community were involved in producing children's material in Rajbansi.

Conducting trainings. Trainings were conducted for teachers, MLE staff and School Management Committees (SMC). The teacher training was intended for all teachers, teaching assistants and teacher in-service. MLE staff was trained on early childhood learning and school management committee members, parents, teachers and students were trained in proposal writing and developing a sustainable plan for MLE program.

Material collection, development and distribution. The MLE staff continued to build the collection of teaching materials and curriculum through the creation of various posters, picture cards, math games, Nepali grammar, math exercise book, English alphabet book and story books. Forty-nine children's materials were produced, including stories, poems and letters. Supplementary materials and lesson plans were developed and revised for KG-G3 and all grades (KG-G5) materials were reviewed, revised, printed and distributed to schools.

Sequencing of languages as medium of instruction. The medium of instruction in pre-primary level was exclusively mother-tongue. Nepali and English as subjects were begun from Grade 1 . From Grades 2-5, other subjects were taught in second language as a transition from mother-tongue.

Teacher preparation and reading assessment. New teachers were recruited in the new teaching approach and reading proficiency in Rajbansi and Nepali in grades 2 and 3 were assessed.

Major achievements. Rajbansi MLE has been greatly successful in achieving its main goal of providing high quality basic education in the mother-tongue within the basic framework and the reality of patterns of language use in Nepal (Tamang, 2019). Major achievements include building construction, preparation of teaching materials in compatible with the socio-cultural setting of the speech community, training to teachers, maintaining high attendance rate, lessening the drop-out rates and creating awareness about the practical importance of mother-tongue (Regmi et al.,2016)

\section{MT Education in Western Tamang}

With the technical support of SIL Nepal, NNLPI has been carrying on MT 
education as a project in Western Tamang since 2017 for children of the Western Tamang speech communities in two community schools located in Tipling, Rubi Valley Rural Municipality, Dhading (NNLPI, 2074 BS). This project was initiated subsequent to conducting a need assessment in the speech communities in December 2015. This program was urgently demanded by the teachers, school management committee (SMC) and parents of the government schools (Regmi and Regmi, 2016b). MT education has been taken as a bridge between mothertongue and English. The goal, approach, issues and challenges as well as strategies used in MT education in Western Tamang are discussed as follows:

Goal and approach of MT education. It aims at developing four languages skills: listening, speaking, reading and writing in the mother-tongue and helping the children to gradually develop such skills in Nepali and English. As in Rajbansi, transitional multilingual approach has been employed in Western Tamang.

Major issues and challenges. As in Rajbansi, there were a number of issues and challenges in framing MT education program. They include selection of schools, framing curriculum and teaching materials, preparing teachers and sequencing of languages as medium of instruction (Regmi, 2018b; Regmi and Regmi, 2019).

Strategies. The issues and challenges were addressed by framing a number of strategies. They are enumerated as follows:

Coordination. Need assessment in community schools located in Jharlang, Borang and Tipling in Dhading district was made prior to framing the MT education program in Western Tamang. Schools were selected on the basis of evaluation of intensity of desire of community and schools. Teachers, school management committee and community were made known about the findings of Needs Assessment through head teachers and approval for the implementation of MT education was received. Teachers, members of school management committees and communities in workshops for framing curriculum and developing teaching materials were involved.

Developing curriculum and reading materials. Curriculum for preprimary has been exclusively developed in consultation with local community representatives. However, Government Curriculum has been fully followed for Grades 1-3. Materials have been developed for pre-reading/pre-writing as well as MT oral language development, MT literacy, number, general knowledge for pre-primary. MT teaching materials are developed by local community for Grades 
1-3. Nepali, English, Math supplementary materials \& teaching aids have been used in conjunction with government textbooks for grades 1-3.

Teaching activities. Child-centered pedagogy and interactive activities were used in pre-primary and Grades 1-3.

Language of instruction. In MT education in Western Tamang, language of instruction was chosen in terms of subjects and levels. Table 3 presents the sequencing of language of instruction in Western Tamang (Regmi and Regmi, 2019).

Table 3: Sequencing of Language of Instruction in Western Tamang

\begin{tabular}{|l|l|c|c|c|c|}
\hline & & KG & G1 & G2 & G3 \\
\hline 1. & Other academic subjects & L1 & L1 & L1/L2 & L2/L1 \\
\hline 2. & English as subject & & L1/L2 & L1/L2 & L2/L1 \\
\hline 3. & Nepali as subject & & L1/L2 & L2/L1 & L2 \\
\hline 4. & $\begin{array}{l}\text { Western Tamang as } \\
\text { subject }\end{array}$ & L1 & L1 & L1 & \\
\hline
\end{tabular}

Recognizing the role and input from teachers, community and experts. Pre-primary and Mother Tongue Grades1-3 curriculum were developed in consultation with the teachers and SMC representatives. SMC representatives, headmasters and teachers were regularly involved in the WT mother tongue materials development. Linguists/ experts were involved in KG curriculum workshop Western Tamang spelling standardization meetings.

Production of materials. Teaching materials were produced for pre-primary and Grade 1. Pre-primary materials include Morning activities teaching aids (WT morning song, calendar, value pocket), Pre-reading/pre-writing exercise book, Number book, WT letter books $1 \& 2 \&$ teaching aids (e.g. letter teaching cards), 14 Theme pictures, 14 Listening stories, 14 WT big books, General Knowledge teaching aids and Teacher's Guide for all subjects. Materials produced for Grade 1 includes WT mother tongue language subject teacher's guide, WT mother tongue student book, Nepali supplementary book, teacher's guide\& teaching aids (e.g. TPR cards), English supplementary book and teacher's guide\& teaching aids (e.g. Alphabet Chart, letter teaching cards, TPR cards). 
Training of teachers and capacity building workshops. Program orientation, pre-service teacher training, in-service teacher training, kindergarten curriculum development workshop and local writer's workshop to develop Western Tamang Grades 1 to 3 textbooks were intended for teachers. Kindergarten curriculum development workshop, local writer's workshop to develop Western Tamang Grades 1 to 3 textbooks and Stakeholders engagement meetings were held for the community.

Monitoring and feedback. Class visit and Kindergarten students' assessment (reading and number) are regularly made. Regular feedback has been gathered from teachers during teacher training to revise materials. Feedback from the local community has also been gathered about the effectiveness of the MT education. Similarly, the challenges in the implementation have been identified.

\section{Major Achievements}

Unlike Rajbansi, Western Tamang has been implemented in the community schools. The community members, parents and teachers have been highly encouraged by the program. Both parents and teachers are highly satisfied with the learning outcome of the children. Number of students in pre-primary level has significantly increased. Reading materials have been prepared in compatible with the socio-cultural settings. Teacher trainings have been found very effective. Still, there is lack of management of teachers in proportion of number of students. Parents are not fully conscious and informed about MT education for their children. Despite such strategies, children are not still regular in the class (Regmi, 2018b).

Table 4 summarizes goals, approaches, major issues and challenges and major achievements in MT education in Rajbansi and Western Tamang. 


\section{Table 4: Goals, Approaches, Major Issues and Challenges and Major Achievements in MT Education in Rajbansi and Western Tamang}

\begin{tabular}{|c|c|c|}
\hline & Rajbansi & Western Tamang \\
\hline Background & $\begin{array}{l}\text { NNLPI implemented in Jhapa from July } \\
\text { 2012- November 2016) by constructing } \\
\text { new buildings in new places }\end{array}$ & $\begin{array}{l}\text { NNLPI has been implementing since } \\
2017 \text { in Dhading in community schools }\end{array}$ \\
\hline Goal & $\begin{array}{l}\text { Provide high quality basic education in } \\
\text { mother-tongue to non-Nepali speaking } \\
\text { children from pre-primary to class five }\end{array}$ & $\begin{array}{l}\text { Develop languages skills in MT and help } \\
\text { children to gradually develop such skills } \\
\text { in Nepali and English }\end{array}$ \\
\hline Approach & Transitional multilingual & Transitional multilingual \\
\hline $\begin{array}{l}\text { Major } \\
\text { issues and } \\
\text { challenges }\end{array}$ & $\begin{array}{l}\text { - Selection of schools and speech } \\
\text { communities } \\
\text { - Framing curriculum and teaching } \\
\text { materials } \\
\text { - Preparing teachers } \\
\text { - Sequencing of languages as medi- } \\
\text { um of instruction } \\
\text { - Getting approval }\end{array}$ & $\begin{array}{l}\text { - } \quad \text { Selection of schools } \\
\text { Framing curriculum and teaching } \\
\text { materials } \\
\text { - } \quad \text { Preparing teachers } \\
\quad \text { Sequencing of languages as medi- } \\
\text { um of instruction }\end{array}$ \\
\hline Stra & $\begin{array}{l}\text { - Coordination } \\
\text { - Conducting workshops } \\
\text { - } \text { Material collection, development } \\
\text { and distribution } \\
\text { - Sequencing of languages as medi- } \\
\text { um of instruction } \\
\text { Teacher preparation and reading } \\
\text { assessment }\end{array}$ & $\begin{array}{l}\text { - } \quad \text { Coordination } \\
\text { Developing curriculum and reading } \\
\text { - } \quad \text { Teaching activities } \\
\text { - } \quad \text { Sequencing of language of instruction } \\
\text { Recognizing the role and input from } \\
\text { teachers, community and experts } \\
\text { - Training of teachers and capacity } \\
\text { building workshops } \\
\text { - Monitoring and feedback }\end{array}$ \\
\hline $\begin{array}{l}\text { Major } \\
\text { achievements }\end{array}$ & $\begin{array}{l}\text { - High quality basic education } \\
\text { - } \text { Building construction } \\
\text { - } \text { Training to teachers } \\
\text { - High attendance rate } \\
\text { - Reduced drop-out rates } \\
\text { - } \text { Creating awareness about the } \\
\text { practical importance of moth- } \\
\text { er-tongue }\end{array}$ & $\begin{array}{l}\text { - Community members are highly en- } \\
\text { couraged } \\
\text { - Parents and teachers are highly sat- } \\
\text { isfied } \\
\text { - Number of students significantly in- } \\
\text { creased } \\
\text { - Reading materials: socio-cultural set- } \\
\text { tings } \\
\text { - Teacher trainings effective }\end{array}$ \\
\hline
\end{tabular}

\section{Model for MT Education Policy in Minority Speech Community}

Indeed, it is not easy to propose a model for MT education policy in the minority speech communities in the present socio-economic and political context of Nepal. However, MT education policy should aim at setting a deliberate system of principles for maintaining the right to attain the quality basic education in the minority speech communities in Nepal. Such policy may be designed by local governments within the basic framework designed by the federal government. Such policy, in principle, may consist of statement, basic principles, objectives, strategies, specific 
actions, desired outcomes, performance indicators, management plans and operational rules and review program. Table 5 briefly outlines MT education policy to be framed in the minority speech communities in Nepal.

\section{Table 5: Outline of MT Education Policy in the Minority Speech Communities in Nepal}

\begin{tabular}{|c|c|}
\hline Basic components & Elaboration \\
\hline Statement & $\begin{array}{l}\text { - MT education policy has been framed to ensure that governments } \\
\text { (Federal, Provincial and Local) fulfill their responsibility of support- } \\
\text { ing the minority speech communities to get quality basic education in } \\
\text { mother tongues as fundamental right. }\end{array}$ \\
\hline Basic principles & $\begin{array}{l}\text { In minority speech communities, MT education is inevitable for cog- } \\
\text { nitive development, reducing drop-out rates, providing quality basic } \\
\text { education and promoting and preserving minority languages in the } \\
\text { country like Nepal. }\end{array}$ \\
\hline Objectives & $\begin{array}{l}\text { - To provide access to the children of minority speech communities to } \\
\text { basic education; } \\
\text { - To provide quality basic education in the minority speech commu- } \\
\text { nities; } \\
\text { - To assure the inclusive education to all the citizens of Nepal; and } \\
\text { - To promote and preserve the mother tongues }\end{array}$ \\
\hline StRATEGIES & $\begin{array}{l}\text { - Empowering the communities } \\
\text { - } \text { Financial and technical support } \\
\text { - Monitoring and supervision }\end{array}$ \\
\hline Specific actions & $\begin{array}{l}\text { - } \text { Needs assessment } \\
\text { - Coordination } \\
\text { - Choice of model: transitional bilingual education } \\
\text { - } \text { Teachers training and feedback }\end{array}$ \\
\hline $\begin{array}{l}\text { Desired } \\
\text { outcomes }\end{array}$ & $\begin{array}{l}\text { - } \text { Quality education assured } \\
\text { - } \text { Slass attendance regular } \\
\text { - } \text { Sife crucial knowledge passed on } \\
\text { - } \quad \text { Uplifting in language vitality } \\
\text { - } \quad \text { Preservation of local culture and traditions } \\
\text { - } \quad \text { Social cohesion and co-existence } \\
\text { - } \text { Migration rate decreased }\end{array}$ \\
\hline $\begin{array}{l}\text { Performance } \\
\text { indicators }\end{array}$ & $\begin{array}{l}\text { - Quality education :Nepali and English improved } \\
\text { - } \quad \text { Elass attendance } \\
\text { - Education for all (inclusive) }\end{array}$ \\
\hline $\begin{array}{l}\text { Management } \\
\text { plans and day to } \\
\text { day operational }\end{array}$ & $\begin{array}{l}\text { - } \text { Class management } \\
\text { - } \text { Teacher management } \\
\text { - Financial management }\end{array}$ \\
\hline Review program & - Bi-annual review and revision \\
\hline
\end{tabular}




\section{Issues and Challenges in Developing MT Education Policy}

MT education policy may be a major component of language policy in a country like Nepal. Such policy sets down the legitimacy of forms and uses of language and implies for status, rights, roles, functions as well as access to language/varieties within a specified polity (Skutnabb-Kangas et al., 2007). Thus, it is not easy to develop or design a MT education policy in the minority speech communities in the present socio-economic and political context of Nepal. It, indeed, requires biased-free identification of issues and such issues have to be wisely addressed and evaluated on the basic principles of social cohesion and inclusion. There are a number of issues in developing MT education policy in the minority speech community. Such issues may be broadly categorized into theoretical and methodological/practical. They are briefly discussedin following ways:

\section{Theoretical Issues}

Theoretical issues may include criteria for language category (majority/minority), language varieties, evaluation of needs of MT education, language loyalty, culture and national unity. They are briefly discussed as follows:

Setting criteria for categorizing languages as majority and minority.There are two basic criteria for categorizing languages in to minority and majority: number of speakers and power (Skutnabb-Kangas \& McCarty, 2007). In Nepal, in terms of number of speakers, languages spoken by over 100,000 speakers are categorized as major and languages spoken by less than that are categorized as minor languages (Seel et al., 2015). Based on this categorization, there are 104 minor languages spoken by $4 \%$ of the total population. In Nepal, till the date, independent censuses of languages/dialects have not yet been conducted. Data gleaned in national censuses about the number of languages and their speakers are not reliable at all. In majority of the minority languages, the real number of speakers is much less than that enumerated in the 2011 census. Till the date, Nepali is the only language with official status. Power may be the most reliable criteria. However, it is a debatable matter. Thus, categorizing languages into majority and minority is a big issue in developing MT education policy in minority speech community in Nepal.

Identifying language varieties. In Nepal, most of the languages are confined to oral forms. Such languages have social as well as geographical varieties. Due to the prolonged language contact many languages are gradually losing their indigenous features in the domains of phonology and lexicon. Besides, many 
languages have not fully linguistically described. Numbers of the varieties of such languages have not yet been identified. Even the core area where such languages are most purely spoken has not yet been unanimously decided. It is not financially feasible to write textbooks in all the varieties of a language. Thus, language varieties are also the issues to be fully addressed in developing MT education policy in the minority speech communities in Nepal.

Needs of MT education. In most of the minority speech communities mother-tongues are deficient in sustainable orality. In such languages, MT education is virtually desired as a subject from pre-primary levels. However, the languages with sustainable orality need to be used as medium especially at the pre-primary level. As language vitality has not yet been assessed in most of the languages, needs of MT education in form of subject or medium is also a great issue in Nepal.

Evaluating language loyalty. In most of the minority speech community, language loyalty is not instrumental. There is a very strong motivation towards English for entering the global world and Nepali as a lingua franca and official language. Local languages and cultures may be promoted through MT education. However, many speech communities are not still confident about advantages of MT education.

Accommodating the forms of culture. Many minority speech communities have been partially assimilated to the dominant cultures. In some speech communities, revitalization process is in progress. Religiously, some people in such communities have adopted Christianity and other religions. MT education policy as socio-cultural process meets issues related to culture: indigenous, Hindunized or others.

Strengthening national unity. National unity is, indeed, strengthened through inclusion. Thus, the minority speech communities should be properly supported for MT education. However, there is another monolingual ideological view that national unity may be weakened by teaching the children of minority communities in their respective mother tongue. This view is indeed detrimental to framing MT education policy in Nepal.

\section{Methodological/Practical Issues}

Methodological/Practical issues include orthography/scripts, model of MT education, sequencing of medium of instructions and cost for management and operation of schools. They are briefly discussed in following manner: 
Orthography/Scripts. In Nepal, most of the languages are confined to oral forms. Such pre-literate languages have to be uplifted to incipient literacy for preparing teaching materials in mother tongues. In Nepal, Sino-spheric minority languages may adapt Tibetan scripts whereas Indo-spheric languages may well be written in Devanagari script. Some languages, viz., Newar, Tamang, Gurung, Limbu, Lepcha, Magar have their indigenous scripts. However, there are some practical difficulties in using them in basic education. Even adopting Devanagari script in compatible with the phonological structures of many languages is not easy. Textbooks prepared in Sambota script have been dumped. Social consensus on orthography is a great matter in the minority speech community. Thus, orthography is a big issue in developing MT education policy in the minority speech community in Nepal.

Models of MT education. There are different models of MT education. Such models are molded by the education policy and language ideology followed in the country. Mother tongue education may be subtractive, viz., shifting students to monolingualism in the dominant language. Such education may be additive, viz., fostering bilingualism and adding another language to mother tongue. There is another popular model referred to as transitional bilingual model in which mother tongue and dominant language are used as the medium of instruction only until the students are able to make transition to receiving all instruction in the dominant language. In this model, MT education is just a bridge. This model does not aim at maintaining the mother tongue. Another model of education is 'maintenance bilingual model' which is fully dedicated to maintaining the minority languages by strengthening the loyalty towards local culture and linguistic diversity. The language of instruction may be largely in L1 or both L1 and L2.There are other models of MT education referred to as early exit and late exit models. In early exit model, the initial instruction is made in MT. This is basically limited to helping the students for clarification. It is principally guided by monolingual ideology. In late exit model, a minimum of forty percent of instructional time is allocated in MT for core subject areas. No detail study has been made as to the appropriate model in the context of Nepal. Transitional bilingual model and 'maintenance bilingual model' may be competing considering the language vitality of the minority languages in Nepal. Yadava et al. (2017) attempted to provide a framework MTB MLE and propose options for selection and sequencing of (i) MT, (ii) Nepali and/or State language(s), (iii) English and (iv) heritage /religious languages as Mols or subjects.

Sequencing of medium of instructions. Nepali, English or mother-tongue may the medium of instruction in basic education. However, many speech 
communities are not still confident about advantages of MT education. Mothertongue may be prescribed as medium of instruction for Grades 1-3. Nepali or a provincial language as second language may be taught from Grade 1. There may a debate: only orally or in written form. As a foreign language, English may also be taught from Grade 1; however, to a limited and oral form. Thus, sequencing the medium of instructions is also the issue in developing MT education policy in minority speech community in Nepal.

Cost for management and operation of schools. Kosonen $(2010 ; 2013)$ notes that MTB MLE reduces number of learners repeating classes, being pushed out of school and leaving school semi-literate without learning as expected. It can save money in the long term provided it is properly supported and implemented. Indeed, in the initial phase, it costs a lot of money for management and operation of schools, preparing books in MT, providing training to teachers and launching programs to encourage the communities for MT education. Thus, cost has been one of the crucial issues in Nepal.

\section{Challenges in Implementing MT Education Policy}

A singular MT education policy has to be framed without delays in order to assure the quality basic education and encourage the minority speech communities to maintain instrumental loyalty towards local culture and linguistic diversity. There are a number of challenges in implementing such policy in Nepal. Broadly, such challenges include sentimental attitude to MT, multilingual communities, lack of trained teachers for modern pedagogy, insufficient classrooms, lack of enough MT teachers, lack of sufficient budget, lack of interest of MT in the communities, continuous change in linguistic composition in schools, lack of permanent structure to ease the access of teachers to local knowledge, folk tales, local culture and technology as well as human resources, use of ICT, lack of teachers to know the process of language transition, lack of writing systems, lack of coordination between the stakeholders, etc. Such challenges have already been highlighted in Kainla et al. (2009), Regmi (2012), Regmi (2013) and Regmi and Regmi (2016). They are briefly discussed here:

Lack of language policy based on pluralism. Till the date, language policy has not yet been framed in Nepal. Some points regarding language policy articulated in legal and policy documents are contradictory. Constitutionally, all mother tongues are languages of nations. All languages are equal in status. However, Nepali written in Devanagari script is a default official language. Language policy so far reflected is not based on the principals of pluralism and inclusion. 
Multilingual Education Implementation Guidelines (2010) has provided authority to the school management committee to decide the language of medium of instruction. Further, it has authorized the local bodies to provide financial support and central level agencies to provide technical support for MLE implementation. Due to the lack of language policy, expected outcomes could not be achieved.

Generating awareness on MT education. There is massive illiteracy in the minority speech communities. Such communities are marginalized politicoeconomically. There is a lack of awareness about MT education. In the context of Nepal, MT education is the instruction given entirely in a child first language (L1), usually with a planned gradual transition to a second language (L2) viz., Nepali or foreign language, viz., English at a specified time period in primary schools. No significant progress has yet been made to persuade the speech communities that MT education facilitates the students to learn core concepts and life crucial knowledge primarily in a familiar language, i.e., MT and improves the learning outcomes by ensuring the quality basic education through the enhancement of the cognitive development in the children. Indeed, MT education improves access to education, reading and learning outcomes, internal educational efficiency, children's self-concept and identity, facilitates learning a second or foreign language and supports local cultures and encourages the speech community involvement (Regmi, 2017b). However, it is not easy to change deep-rooted mindset about languages, i.e Nepali and English as medium of instruction in the basic education. Most of the minority speech communities, which are gradually shifting to the dominant languages, and mainstream cultures, lack instrumental attitude towards the MT they speak.

Managing mixed class of divergent socio-linguistic backgrounds. It is easy to implement MT education policy in a community wherein all the students have the same language as mother tongue. However, it is very difficult to implement MT education policy in a multilingual community (Kainla et al. 2009,p.2). It is really challengeable to apply new instructional approach due to the lack of trained teachers, insufficient class rooms and lack of sufficient number of mother tongue teachers. In a multilingual country like Nepal, except in a few schools located in Terai and Himalayan regions, there are students from divergent socio-linguistic backgrounds. In such cases, it is not easy to address the requirements of the textbooks and reading materials compatible with their respective sociolinguistic backgrounds. 
Identifying languages/dialects. A comprehensive linguistic census has not yet been conducted in Nepal. Thus, Nepal does not have any detailed, reliable, comprehensive and all-inclusive picture of the situation of the languages and their dialects till today. The number of languages and dialects so far counted in the population censuses of Nepal (1952/54-2011) is not only inconsistent but also unreliable. There is always disagreement among the members of the speech communities about the status of the languages used in the textbooks. The policies and programs framed on the basis of such information naturally cannot bear the expected results.

Evaluating sustainable language use. Many minority languages in Nepal are not transmitted to the younger generations. It is not fruitful to implement MT education policy in the languages which lack sustainable orality. Languages with sustainable identity have to be first raised to sustainable orality for the language to be used in education. However, evaluating sustainable language use in the present context is a very challengeable in Nepal.

Developing orthography. Many languages are preliterate and still undescribed or poorly described. A few languages like Newar, Maithili, Limbu, Bhojpuri, Awadhi, Hindi, Urdu and Bhote (Sherpa) have already established literate traditions. Some languages like Tharu, Tamang, Magar, Gurung, Thulung, Bantawa, Chamling, Khaling, Kulung, Thakali, Sherpa, Rajbansi, Bahing and Thami are trying to go to the process of standardizing literate traditions (Turin, 2004). Many languages like Chepang, Bhujel, Kaike, Santhali, Bote, Baram, Rana Tharu, Yohlmo, Koyee lack writing systems. It is not an easy task to propose a writing system for a preliterate language in Nepal. MT education is impossible unless a writing system fully and systematically represents the phonological system of a language. Textbooks and other reading materials cannot be developed with uplifting orality languages into incipient literacy. In many minority languages, basic sounds have not yet been systematically identified. Adapting sounds into Devanagari scripts has also been facing problems.

Managing funds. MT education indeed requires a huge amount of money for operating schools, preparing textbooks and reference materials, trainings and workshops and monitoring and evaluation. In federal system, basic and secondary education has been totally left in the responsibility of the local bodies. Local bodies are not instrumentally ready to allocate funds in MT education. Such funds may not be generated in the socio-economically marginalized minority speech communities in Nepal. 


\section{Preparing appropriate textbooks and reference materials Preparing} textbooks and reference materials in compatible with the local cultures and traditions is not an easy task. It is a very difficult task to collect the valid local life crucial knowledge, folktales, traditions and cultures, traditional technology and human resources. Textbooks and reference materials developed within the framework of textbooks in Nepali have not been able to encourage the speech communities to implement MT education in Nepal.

Managing trained mother-tongue teachers. Managing trained mother tongue teachers for basic education is a challenge to the communities in Nepal. There is also a lack of funding for training the teachers. With untrained teachers it is not possible even to implement the textbooks and other materials appropriately in the multilingual classes.

Integrating ICT into MT education. Many crucial challenges such as lack of sufficient textbooks, reading materials and trained teachers may satisfactorily met and learning outcomes can be expectedly improved by integrating ICTs into MT education. However, due to the lack of teacher confidence, lack of teacher competence, resistance of change and negative attitudes, lack of effective training, lack of accessibility, lack of technical support, integrating ICT into MT education has been a difficult task.

Forming positive attitudes in teachers. Mother tongue education is not compulsory in Nepal. Private schools are not legally bound to implement MT education in Nepal. Community schools, which are expected to implement MT education policy, are lacking teachers with positive attitudes towards mother tongues.

\section{Strategies for Implementing MT Education Policy}

MT education policy, which is inevitable to be developed and implemented in the minority speech communities, requires framing a number of strategies for its proper implementation in the present context of Nepal. They are briefly discussed as follows:

Framing pluralistic and inclusive language policy. Both the constitution and education act have guaranteed the right of the speech communities to receive education in respective mother tongues. However, language policy has not yet been framed in Nepal. Even new education policy has also been delayed. First and foremost, language policy has to be framed on the principles of pluralism and inclusion. It sets framework for the use of languages in the different domains 
like education, mass media and office. It demands the most reliable data on the number of languages and their dialects as well as their speakers.

Conducting linguistic census. The numbers of languages gleaned by the national censuses are erroneous. It is to be noted that dialects have not yet been officially documented in Nepal. Mother tongue education is not basically intended to be given in standardized dialects. Thus, the number of indigenous, crossbordered and foreign languages and their speakers has to be reliably identified by conducting linguistic census. More importantly, social and geographical varieties of all the languages have to be identified.

Identifying minority languages. Minority languages have to be identified by setting criteria on the ground reality. Primarily, power, indigenousness and number of speakers may be the basic criteria. In Nepal, indigenousness may be the most important criteria for identifying minority languages.

Framing inclusive education policy. Education policy should be framed on the principles of inclusion. Such policy should articulate MT education with transitional model as compulsory in those speech communities where the form of speech has been sustainably used in oral form. However, it is not easy to assess sustainable language use in the minority speech communities in Nepal.

Assessing sustainable language use. By applying the FAMED conditions (Regmi,2019), minority languages have to be assessed and framing appropriate strategies, languages with lower levels have to be raised to the upper levels until they reach the sustainable orality levels. ${ }^{7}$

Needs assessment. Needs assessments have to be carried out the speech communities having languages with sustainable orality. On the basis of the intensity of the desire and needs of the community, MT education may be implemented.

Uplifting of sustainable orality language. The speech communities selected on the basis of needs assessment have to be involved in uplifting sustainable orality languages into incipient literacy by developing a writing system with the consent of communities.

Conducting workshops and trainings. Workshops should be conducted

7 FAMED is an acronym. F stands for functions, A for acquisition), $\mathrm{M}$ for motivation, $\mathrm{E}$ for environment and $\mathrm{D}$ for differentiation. 
on teaching approach and writing materials. Participants from the speech community were involved in producing children's materials. Trainings should be conducted for teachers as well as School Management Committees (SMC).

Developing textbooks and reference materials. Textbooks and reference materials should be based on the local contexts and local needs. They should be prepared involving the speech communities incorporating the essential cultural matters with the direct supervision of linguists, educationists and the local teachers. There should be maximum adaptation of the materials to the local contexts. They should be interesting to both students as well the teachers.

Integrating ICT into MT education. ICT has to be integrated into MT education for collecting and analysing the data, producing sufficient number of textbooks and reference materials, pedagogical grammars and trilingual dictionaries (MT, dominant language and English) and pictorial dictionaries.

Managing funds. Sufficient funds have to be made available to the communities to implement MT education.

Monitoring and evaluation. Regular monitoring and evaluation has to be conducted to evaluate the effectiveness of MT education and to get feedbacks.

\section{Summary and Conclusions}

In this paper, I have examined and explored some major issues and challenges (both theoretical and methodological) in developing and implementing mother-tongue education policy in the minority speech communities in Nepal. Moreover, I have suggested some strategies with reference to mother-tongue education implemented in Western Tamang and Rajbansi for meeting those challenges. In order to facilitate the constitutional right of receiving basic education in mother tongue in minority speech communities in Nepal and desire to preserve, promote and develop languages and scripts, an all-inclusive and separate MT education policy has to be immediately framed by wisely taking the major issues into consideration in compatible with the socio-linguistic context. New education policy has not yet come into existence. The legal provisions so far made are not yet consolidated and compiled. Some of them are still contradictory. Most of the minority languages lack sustainable orality. Neither the government nor the communities are fully aware and confident about the need of MT education. MT education is almost optional. In the present context of Nepal, it is not easy to develop an encouraging MT education policy in the minority speech communities. There are 
a number of issues related to models, sequencing of languages, pedagogy, teaching materials and management and operation of schools. There are a number of challenges in implementing MT education policy in such communities. The challanges include: lack of conducive and compulsory transitional bi/multilingual education policy, limited resources, lack of adequate MLE textbooks, lack of human resources (lack of trained teachers), lack of positive attitudes (parental resistance), political ambivalence, lack of proper school management, lack or ineffective use ICTs and lack of conceptual clarity. Provided strong commitments are made by the governments (local, provincial and central) and strong desires are made by the communities, MT education policy may be effectively implemented in such communities in Nepal. Such language policy must encourage the learners to develop loyalty towards local cultures and language diversity in Nepal. Most importantly, the total mindsets and policy for basic education has to be fundamentally changed. Mother-tongue education implemented in Western Tamang and Rajbansi may have provided insights for developing MT education policy and some ways-out to meet the issues and challenges in the implementation of such policy in Nepal. MT education, a new instructional approach, is inevitable to ensure improved academic achievement, increased efficiency and promote greater social cohesion and inclusion.

\section{References}

\section{In English}

Central Bureau of Statistics (CBS). (2012). National population and housing census 2011: National report. Kathmandu: National Planning Commission.

Eppele, J. W., M. Lewis, P., Regmi, D. R., \& Yadava, Y. P. (Eds.). (2012). Ethnologue: Languages of Nepal. Kathmandu: Linguistic Survey of Nepal (LinSuN) and SIL International.

Government of Nepal. (2015). The constitution of Nepal. http://www.lawcommission. gov.np/en/wp-content/uploads/2018/09/10272.pdf

Government of Nepal. (2018). The act relating to compulsory and free education. http:// www.lawcommission.gov.np/en/archives/20734

Kosonen, K. (2010). Cost-effectiveness of first language-based milingual and multilingual education. In P. Kadel (Ed.) Multilingual education in Nepal (pp. 27-33). Kathmandu: Language Development Centre-Nepal.

Kosonen, K. (2013). MLE: The cost issue. A paper presented at $4^{\text {th }}$ International Conference on Language and Education: Multilingual education for all in asia and the pacific - policies, practices and processes, 6-8 November, 2013 at Imperial Queen's Park Hotel, Bangkok, Thailand.

Lewis, M. P. \& Simons, G. F. (2010). Assessing endangerment: Expanding fishman's GIDS. 
Revue Romaine de Linguistique, 55, 103-120.

NLPRC (National Language Policy Recommendation Commission). (1994). The report

of national languages policy recommendation commission 1994 (2050VS), National Language Policy Recommendation Commission, Academy Building, Kamaladi, Kathmandu, Nepal.

Regmi, A. (2013). Ascertaining access to mother tongue-based multilingual education for ethno-linguistic communities of Nepal. A paper presented at $4^{\text {th }}$ International Conference on Language and Education: Multilingual Education for All in Asia and the Pacific - Policies, Practices and Processes 6-8 November, 2013 Imperial Queen's Park Hotel, Bangkok, Thailand.

Regmi, D. R. (2012). Multilingual education in Nepal: Policy and practice. T.U. Bulletin Special, 2012, 136-149.

Regmi, D. R., Sharma, S., Tiwari, J. L., Rijal N. \& Basnet G.R. (2016). Sil language, Education and Development (Nepal) Project. A report of final evaluation submitted to Social Welfare Council, Samaj Sewa Bhawan, Lainchaur, Kathmandu, Nepal.

Regmi, D. R. (2017a). Convalescing the endangered languages in Nepal: Policy, practice and challenges. Gipan, 3(1), 139-149.

Regmi, D. R. (2017b). Integrating ICT into MTBE in the developing countries: Prospects, challenges and strategies. Nepalese Linguistics, 32, 94-101.

Regmi, D. R. (2018a.) Use of minority languages of Nepal in media: Scope and relevance. Aligarh Journal of Linguistics, 7(1), 38-52.

Regmi, D. R. (2018c). Preserving and promoting the endangered languages of Nepal: Policy, practices and challenges, Mother Language 2 (1), 24-44 December, 2018.

Regmi, D. R. (2019). Preserving endangered languages of Nepal: From sustainable use model perspective, a paper presented at the International Seminar on Mother Languages: Promotion and Preservation organized by the International Mother Language Institute (IMLI), Dhaka, for the celebration of International Mother Language Day, 2019, 22 February 2019.

Regmi, D. R. \& Regmi A. (2016a). Role of multilingual education planning and policy [mepp] for the development of indigenous languages and cultures in Nepal." A paper presented at the International Conference on Language Policy in Multicultural and Multilingual Settings 8-11 February, 2016 The University of Mandalay,Mandalay, Myanmar.

Seel, A. Yadava, Y.P., \& Kadel, S. (2015). Medium of Instruction and Languages for Education (MILE): Ways Forward for Education Policy and Practice. A paper presented at the Stakeholder Consultation Workshop held on $17^{\text {th }}$ April, 2015, Kathmandu.

Seel, A, Yadava, Y. P. \& Kadel, S. (2017). Medium of instruction and languages for education (MILE): Ways forward for education policy, planning and practice in Nepal. Kathmandu: Transcend Vision Nepal. 
Skutnabb-Kangas, T \& McCarty T. L. (2007). Key concepts in bilingual education: Ideological, historical, epistemological, and empirical foundations. In Jim Cumins, and Nancy Hornberger (eds.). 5: Bilingual Education, Encyclopedia of Language and Education (2nd ed.). The Netherlands: Kluwer Academic Publisher.

Skutnabb-Kangas, T. and Mohanty, A. (2009). Policy and strategy for MLE in Nepal. A report submitted to Inclusive Section, Department of Education, Ministry of Education, Sanothimi Bhaktapur.

Tamang, D. (2019). Mother tongue based multilingual education program: An effective approach to teaching in Rajbansi Language Community. Asian Journal of Multidisciplinary Studies, (7(1), 24-37.

Turin, M. (2004). Minority language policies in Nepal and the Himalayas. Position paper for scalla 2004 working conference on crossing the digital divide: Technologies to meet human needs, 5-7 January, 2004, Kathmandu.

World Education Forum (2015). Education 2030: Incheon feclaration and framework for action. http://uis.unesco.org/sites/default/files/documents/education-2030incheon-framework-for-action-implementation-of-sdg4-2016-en_2.pdf

Yadava, Y. P. (2010). Forward. In Kadel, Pushker (ed.) Multilingual Education in Nepal. Kathmandu: Language Development Centre-Nepal.

Yadava, Y. P. (2013). MLE policy and practices in Nepal: An appraisal. A paper presented at $4^{\text {th }}$ International Conference on Language and Education: Multilingual Education for All in Asia and the Pacific - Policies, Practices and Processes, 6-8 November, 2013 Imperial Queen's Park Hotel, Bangkok, Thailand.

Yadava, Y. P. (2014). Language use in Nepal. Population Monograph of Nepal 2014. 5172. Kathmandu: Central Bureau Statistics.

Yadava, Y. P., Rai , M., \& Adhikary, K. P. (2017). Mother tongue-based multilingualeducation (MTB MLE) in Nepal: A framework in the context of federalism. A report submitted to Department of Education (DoE)/Ministry of Education (MoE) Kathmandu, Nepal and Executive Office, USAID/Nepal, U. S. Embassy, Maharajgunj, Kathmandu, Nepal and submitted by Transcend Vision Nepal (TVN) Pvt. Ltd., Sinamangal, Kathmandu, Nepal.

Yadava, Y. P. (2018). Envisaging a framework for mother tongue based multilingual education (MTB MLE) in the federal context of Nepal, Mother Language, 2(1), 45-90.

\section{In Nepali}

Kainla et al (2009)/काइँला, बैरागी, लोक बहादुर थापा, योगेन्द्र प्रसाद यादव, अरूणकुमार तिवारी, दिने श श्रेष्ठ, विक्रममणि त्रिपाठी र सुशन आचार्य (२००९ इ.) नेपालमा बहुभाषिक शिक्षाका नीति तथा रणनीतिहरूको पुनरावलोकन, सानोठिमी: बहुभाषिक शैक्षिक कार्यक्रम, शिक्षा मन्त्रालय।

NNLPI(2073BS)/ नेपाली राष्ट्रिय भाषाहरू संरक्षण संस्था (२०७३ वि.सं.), बहुभाषिक शिक्षा कार्यक्रम २०७२/७३ को प्रतिवेदन, नेपाली राष्ट्रिय भाषाहरू संरक्षण संस्था, ललितपुर, नेपाल

NNLPI(2074BS)/ नेपाली राष्ट्रिय भाषाहरू संरक्षण संस्था(२०७५ वि.सं.), बहुभाषिक शिक्षा कार्यक्रम 
२०७४ /७५ को प्रतिवेदन, नेपाली राष्ट्रिय भाषाहरू संरक्षण संस्था, ललितपुर, नेपाल

रेग्मी, दानराज र अम्बिका रेग्मी (२०१६ इ.), पश्चिमी तामाङ भाषामा आधारित बहुभाषिक शिक्षाको आवश्यकता मूल्याङ्कन सर्वेक्षण, नेपाली राष्ट्रिय भाषाहरू संरक्षण संस्थामा जनावरी २०१६ मा बुभाएको प्रतिवेदन।

रेग्मी, दानराज (२०१७ इ.), 'नेपालमा भाषाहरूको स्थिति र भाषिक सर्वेक्षणः समीक्षात्मक विश्लेषण', गिपान, अङ ३.२:२२८/२६०, नोभेम्बर, २०१७।

रेग्मी, दानराज (२०१८ इ.), पश्चिमी तामाङ भाषामा मातृभाषामा आधारित बहुभाषिक शिक्षा कार्यक्रमको मध्यावधि मूल्याङन (Mid-term Evaluation), नेपाली राष्ट्रिय भाषाहरू संरक्षण संस्थामा १२ फेब्रुअरी, २०१८ मा बुभाएको प्रतिवेदन।

रेग्मी, दानराज (२०१८ इ.) 'नेपालका भाषाहरूको समाजभाषावैज्ञानिक स्थितिः समीक्षात्मकविश्लेषण', दून पुस्तकालय एवम् शोधकेन्द्र, देहरादूनद्वारा आयोजित "केन्द्रीय तथा पश्चिमी हिमाली भेगमा बोलिने लोपोन्मुख भाषाहरू" विषयमा २०१८ को अक्टोवर ११ देखि १३ सम्म अल्मोडामा अवस्थित कुमाउँ विश्विविद्यालयको सोवन सिँह जीना परिसरमा सज्चालन गरिएको अन्तर्राष्ट्रिय सझोष्ठिमा प्रस्तुत गरिएको परिमार्जित कार्यपत्र। रेग्मी, दानराज र अम्बिका रेग्मी (२०९९ इ.) "पश्चिमी तामाङ भाषिकामा मातृभाषामा शिक्षाः आवश्यकता, कार्यान्वयन प्रत्रिया तथा प्रभावकारिता", KĀITEN (The Journal of Tamang Studies), Vol = 1 = $2 \mathrm{M} 22-32=$

योज्जन तामाङ, अमृत (२०६९ वि.सं.) 'बहुभाषिक शिक्षाः नेपालमा अभ्यास र अनुभव', नेपाल प्रज्ञा(प्रतिष्ठान, काठमाडौँद्वारा $९$ फाल्गुन २०६९ मा अन्तर्राष्ट्रिय मातृभाषा दिवसको सन्दर्भमा आयोजित अन्तर्राष्ट्रिय मातृभाषा सझोष्ठिमा प्रस्तुत कार्यपत्र।

\section{Annex 1: Languages with Sustainable Orality in Nepal}

\begin{tabular}{|l|l|l|}
\hline 1. & $\begin{array}{l}\text { 6a Vigorous } \\
30(24.39 \%)\end{array}$ & $\begin{array}{l}\text { Koyee, Kaike, Kagate, Kisan, Kuki, Kham, Khaling, Nepali } \\
\text { Sign Language, Jumli, Gangai, Bahing, Byansi, Raute, Lhopa, } \\
\text { Thulung, Yholmo, Wambule, Batadeli, Achhami, Bajhangi, } \\
\text { Tajpuriya, Bajureli, Darchuleli, Dailekhi, Khas, Musalman, } \\
\text { Panjabi, Dadeldhuri, Bajjika }\end{array}$ \\
\hline 2. & $\begin{array}{l}\text { 6b Threat- } \\
\text { ened }\end{array}$ & $\begin{array}{l}\text { Angika, Uranw, Kulung, Khadiya, Gurung, Ghale, Chamling, } \\
\text { Chepang, Chhntyal, Jirel, Jerong, Thanmi, Darai, Dungma- } \\
\text { li, Dhimal, Puma, Bantawa, Belhare, Bote, Magar (Magar } \\
\text { Dhut), Manange, Majhi, Meche, Mewahang, Yakkha, Yam- } \\
\text { phu, Raji, Limbu, Lohorung, Sampang, Sunuwar, Nagami, } \\
\text { Mijo,Banakariya, Surel, Dhuleli, Dolpali, Pahari, Chhintang, } \\
\text { Athapahariya, Kisan, Hariyani, Oriya, Sindhi, Asami, Mal- } \\
\text { pande, Kurmali, Gadhawali, Rai, Magahi and Koche }\end{array}$ \\
\hline
\end{tabular}

